\title{
PART-MACHINE GROUP FORMATION WITH ORDINAL-RATIO LEVEL DATA \& PRODUCTION VOLUME
}

\author{
Kumar, L.* \& Jain, P. K.** \\ * Department of Mechanical Engineering, J.M.I., New Delhi-110025, India \\ ${ }^{* *}$ Department of Mechanical and Industrial Engineering, I.I.T., Roorkee, India \\ E-Mail: lokeshkrsax@rediffmail.com; pkjain123@gmail.com
}

\begin{abstract}
This work presents an algorithm for design of cellular manufacturing system. It considers ordinal level data and ratio level data. We consider sequence of operation for every component as ordinal level data. The ratio level data includes operation time per unit, production volume \& machine capacity. Adapted design activity model \& image representation in computer vision is used to model ordinal-ratio level data. Orthographic view part grouping is used for part family formation. Machines are allocated on basis of their net utilization for a part family. Performance of algorithm is comparable \& of good quality with existing methods in its class. To validate the result, a two way ANOVA technique is used, and on simulated example the F-ratio is enumerated. It is observed that production volume has significant influence on cell configuration and cell performance. It is concluded that the change in production volume mixes may need reconfiguration \& capacity scaling according to recommendation of algorithm \& ANOVA analysis. To facilitate industrial application, it can be implemented by using free software, Scilab and/or commercial softwares.

(Received in August 2008, accepted in November 2008. This paper was with the authors 1 month for 1 revision.)
\end{abstract}

Key Words: Cellular Manufacturing, Part Families and Machine Cells, Algorithm, ANOVA

\section{INTRODUCTION \& LITERATURE REVIEW}

Cellular Manufacturing (CM) is an application of group technology. It aims at a harmonious assimilation of manufacturing facilities of a company. It relies on manufacturing similarity concept of group technology. It allows the benefit of flow production organization to be obtained in a job shop or batch shop production. The first step towards the design of a cellular manufacturing system is the identification part families and machine groups. The more closely the assumption made are to reality (i.e. shop floor realities), the better the cell design.

Most methods are based on machine component incidence matrix (that is 0 \& 1) alone [111]. A number of researchers proposed similarities coefficients based approaches to solve the CF problem in the literature. An approach is proposed that is based upon the calculation of an average voids value $(A V V)$, which indicates the average number of newly produced voids, when a pair of machine groups is combined [12]. Studies indicated that similarity coefficients based methods (SCM) are more flexible than other CF methods [13].

Some components have to travel to another cell for further operations. Different order/sequence of machine cells allocation may result in different total intercellular distance unit. If the production volume of each part is very large, then the total number of intercellular movement will be further larger. Therefore, operation sequence and production volume are very important production factor $[11,14,15]$. Beside it, capacity is other important shop floor parameter, influencing progress of part production and cell performance [16].

Venugopal \& Narendran made use of genetic algorithm for clustering. Nair \& Narendran developed a method (CASE, 1998) [15] of the non-hierarchical type on the basis of sequence 
data only [14]. Nair and Narendran proposal algorithm ACCORD (1999) [16] considering ordinal and ratio level data. However, they considered unity production volume for all parts. George et al. (2003) [14] also proposed an analytical iterative clustering algorithm for cell formation with ordinal level and ratio level data. However, they also considered unity production volume for all parts. This may yield sub-optimum solution due to ignoring an important shop floor reality i.e. production volume, while modeling shop floor realities as ordinal level data and ratio level data for part family and machine group formation. Beside it, to the best knowledge of author, no researcher other than Nair and George [15, 16] had considered ordinal level and ratio level data simultaneously in their simple SCM models.

Principal components analysis is used for evaluating the feasibility of cellular manufacturing without initial-part matrix clustering [3]. An approach is proposed for machine cells formation by applying factor analysis to the matrix of similarity coefficients [2]. The proposed approach has not considered other important production factors such as operation sequence, volumes \& processing times. An approach is proposed for machine cells formation by applying a multivariate analysis model to find the Eigen values and eigenvectors on the double centering matrix [8]. This work has also not considered other production data such as sequence, volumes \& processing times. Lokesh Kumar [17] proposed an algorithm with operation sequence, operation time \& production volume using principal components analysis. However, he did not consider machine capacity in his model.

Most existing methods require an a priori specification of the upper bound on the number of machines within a cell and/or the number of cells. This contradicts the fundamental philosophy of GT that groups exist naturally. The task of the analyst is to identify them if they exist [9]. There is limited industrial application due to unavailability of softwares supporting solution of CF problems or these are expensive softwares [18]. Most of the time it is required to have knowledge of programming, difficult \& complex optimization techniques such as genetic algorithms, neural networks etc. This work develops an algorithm, APORVUIT. It stands for an Algorithm with Part Ordinal level data, Ratio level data, Production Volume, Machine Utilization Gain \& Inter Cell Travel Loss for formation of part families \& machine cells.

\section{APORVUIT - METHODOLOGY}

The objective of group technology layout is to subdivide the total number of components and machines into subgroups of machine-component cells such that the required machines of all components which are assigned to each cell are maximally available within that cell it.

\subsection{Modeling for machine-part analysis and grouping}

In this problem, parts are assumed as objects and machines which process the part, are treated as attributes of that part. The processing requirement of parts can be represented in form of object-attribute (i.e. part-machine) incidence matrix. The rows of this matrix represent machines. Column of matrix represent the parts. Let us treat this matrix as Machine Sequence Part Matrix; MSPM. Numeral in a cell of matrix represents sequence number of that part on machine.

Step 1 Ratio Level data Model: The ratio level data model includes operation time per unit, production volume and machine capacity. These important factors represent shop floor reality. Part load ratio is taken as model for these data. Part load ratio (PLR) is defined as ratio of product of operation time and production volume to machine capacity. This is represented in Part Load Ratio Matrix (PLRM). 
Step 2 Ordinal Level Data Model: Sequence of operations of a part is known as ordinal level data. To model ordinal level data, it is represented in matrix form by model given by Lokesh Kumar $[17,19]$. Due to length of paper constraint, it is difficult to give detailed description; readers are advised to refer the paper [17]. In part-family grouping problem, each part moves machine to machine in sequence. To model machine sequence, we make Part Machine to Machine Sequence Matrix (PMMSM) for each part. If the part visits the machine, corresponding element is assigned as unity. Number of one in this matrix represents sequence number of machine. It is as follows [17]:

1. Allocate zero to all elements of row of machine if part does not visit that part.

2. If parts visit a machine first in sequence, allocate 1 to element of rows of that machines and column of all machines required by part.

3. Allocate zero to all elements of row of machine if part does not visit that part.

4. If parts visit a machine first in sequence, allocate 1 to element of rows of that machines and column of all machines required by part.

5. If parts visit a machine second in sequence, allocate 1 to element of rows of that and column of machine required by part, (excluding the machine that is visited first in sequence.

6. If a part visit a machine third in sequence, allocate 1 to elements of rows of that and columns of machines required by part excluding the machine that is visited first and second in sequence.

7. Above procedure is followed for other machine sequence.

Now, Part Machine to Machine sequence operation Time Volume/Capacity Matrix (PMMSTV/CM) is formed. For this multiply Part Load ratio of a part on a machine with all ones of corresponding machines for that part in PMMSM Matrix.

Step 3 Ordinal-Ratio level data Model: For combined Model of ordinal and ratio level data, image representation technique in computer vision [20], used by Lokesh Kumar [17] is employed here. Readers are advised to refer the paper [17]. Now, make a matrix Machine Sequence Part Load Ratio Matrix (MSPLRM), with column (p) representing parts and rows $\left(m_{p}=m \times m\right)$. For each part, rows of PMMSTV/CM are arranged into column one by one to make one dimensional column vector (i.e. image vector of that part). All image vectors (i.e. parts) are placed column-wise to form big image vector (i.e. image matrix).

\subsection{Ordinal-ratio level data model analysis}

Now, our aim is to group input variable (machine/parts) into few factors (i.e. cells) which underlie the input variables. In other words, cell formation need dimension reduction on the basis of some similarity measure or coefficients.

Step 1 Ordinal-Ratio level data Model Standardization: Now, SMSPLRM matrix is formed from MSPLRM matrix. Here, elements of MSPLRM are standardized by using formula [21].

$$
Z(I, J)=\operatorname{SMSPLRM}(I, J)=[\{\operatorname{MSPLRM}(I, J)-\operatorname{MSPLRM}(J)\} / \operatorname{SD}(J)]
$$

where, MSPLRM $(J)$ is the mean of elements of $J^{\text {th }}$ column of matrix MSPLRM. SD $(J)$ is standard deviation of elements of $J^{\text {th }}$ column of matrix MSPLRM.

Step 2 Part-part Correlation Model: Now, PPCM matrix is formed from SMSPLRM matrix on the basis of similarity coefficient [22]. It is given as:

Element of PPCM: $\quad \operatorname{PPCM}(I, J)=1$, if $I=J$,

otherwise, 


$$
\operatorname{PPCM}(I, J)=\frac{1}{m_{p}} \sum_{k=1}^{m_{p}}[\operatorname{SMSPLRM}(K, I) * \operatorname{SMSPLRM}(K, J)]
$$

Here, $m_{p}=m \times m$.

This matrix represents measure of similarity between parts.

Step 3 Part-part Correlation Model Reduction: Principle component analysis transforms a given set of interrelated variables into a new set of original variables, called the principal components \& is orthogonal to each other. So, the correlation between them is zero. Detailed description of this approach can be found in the relevant literature [17, 21, 23].

Assuming the parts as the original set of variables and the correlation matrix PPCM, explaining the correlation between each pair of parts, we proceed to use the PCA framework for grouping the parts into separate independent clusters.

In the PCA method, the cells are extracted out by the eigen value-eigenvector analysis of the correlation matrix as presented in Eq. (2).

It finds a small number of principle components, recovering as much variability in data as possible. It means finding eigen vector and eigen values for equation,

$$
\operatorname{det}\left(P P C M-\lambda(J) \cdot I_{m}\right)=0 ; J \in(1, p)
$$

where $I_{m}$ is identity matrix.

$$
\lambda(J) \in\left(\lambda_{1} \geq \lambda_{2}, \ldots \ldots \ldots, \lambda_{p}\right) \text { are eigen values (real and non-negative) }\left\{F_{1}, F_{2}, \ldots \ldots \ldots \ldots . ., F_{p}\right\}
$$

are corresponding eigen vectors of matrix PPCM.

Step 4 Orthographic View Part Grouping Analysis (OVPGA): Each row of PCA matrix, represents a point in multidimensional space (number of axis / dimension equal to number of principle components). The line joining this point and origin of coordinate system is a vector (also that part). Orthographic projection of this vector in space on a plane of projection made of first and second principle components represents that part. This projected view is used for grouping purpose [13].

Represent $\mathrm{X}$-axis as first principle component and $\mathrm{Y}$-axis as second principle component (i.e. eigen vectors), now plot each variable (i.e. parts) with coordinates as (principle component 1 , principle component 2). Join this point with zero of coordinate system with a line. This line represents that part. Thus, draw Orthographic View. Angular distance between lines on Orthographic View is taken as measure of similarity. Parts with low angular distance become part of a family. Plot will shows groups of part with almost same angular distance from first principle component.

- Two parts having low angular distance, assign to same cell.

- Two parts having almost $180^{\circ}$ angular distance, assign to different cells.

- If part does not belong to any three categories, it is exceptional part.

(a) Compute angular distance of exceptional parts $\left(k_{p}\right)$ with first principle component axis, $\theta_{k i}$.

(b) Compute angular distance of exceptional part with other non-exceptional part (i), $\theta_{i k e}=\left|\theta_{i}-\theta_{k e}\right|$, where $\theta_{i}$ is angular distance of $i^{\text {th }}$ part with first principle component.

Find minimum $\theta_{i k e}$ and $k_{e}$ part is a member of part group for which $\theta_{i k e}$ is minimum [12].

\subsection{Assignment of machine to part families (i.e. machine grouping)}

Now machines are allocated to the part families. The machine allocation should meet basic aim of maximum utilization of machines (i.e. resources) \& minimum loss due to intercell travels. 
Step 1 Computes Machine Utilization Net gain (MUNG) opportunity: For each machine, computes Machine Utilization Net gain (MUNG) opportunity in different part families (i.e. cells). MUNG of a machine $I$ for part family $K$ is defined as difference of machine utilization opportunity gain (MUOG) of machine $I$ for part family $K$ and Intercell travel loss (ICTL) for machine $I$ for part families other than $K^{\text {th }}$ part family. Machine utilization opportunity gain (MUOG) of machine $I$ for part family $K$ is defined as sum of total processing time of all parts in part family $K$. Total processing time of $J^{\text {th }}$ part is multiplication of processing time of part $J$ on machine $I$ and production volume of $J^{\text {th }}$ part. Processing time of part $I$ is sum of operation time, setup time and other idle times. Intercell travel loss (ICTL) for machine $I$ and part family $K$ is sum of intercell travel losses for machine $I$ due to movement of parts belonging to part families other than part family $K$ [12].

$M U N G$ in a part family $K$ is given as: $M U N G=M U O G-I C T L$

$M U O G$ in a part family $K$ is given as:

$$
\begin{aligned}
& \text { MUOG }(K)= \sum[(\text { Part load } / \text { unload time }+ \text { Tool change time }+ \text { Operation time }) \times \\
&\times \text { Production Volume }+ \text { Setup time }], \text { for all parts } .
\end{aligned}
$$

Intercell Travel loss with other part families is given as:

$$
\begin{aligned}
I C T L & =\sum_{K 1=1}^{n_{\text {opt }}} \text { Intercell Travel Loss for machine } I \text { for part families }(K 1 \neq K) \\
& \text { other than part family } K \text { (when machine is assigned to part family } K \text { ) }
\end{aligned}
$$

ICTL for a part is given as:

ICTL for a part $=($ Load $/$ Unload time + Travel time in material handling device $) \times$ $\times$ Production volume

Step 2 Machines are allocated on the basis of MUNG, MUOG, and ICTL as:

(a) Allocate the $m^{\text {th }}$ machine to a part family for which MUNG is largest.

(b) If tie occurs among cells, allocate the machine on the basis of MUOG.

(c) If tie occurs among cells, allocate on the basis of total operation cost opportunity for machine in a part family.

(d) If tie occurs; allocate on the basis of minimum intercell travel loss, ICTL.

If tie occurs, allocate on the basis of idle time cost [12].

\subsection{Measure of performance}

The measure group efficiency (i.e. GE) treats all operation equally \& does not represent true grouping performance for ordinal and ratio level data. Harhalakis et al. [10] proposed group technology efficiency (GTE), considering ordinal level data (i.e. sequence of operation). Grouping technology efficiency is defined by Eq. (10). Maximum numbers of intercell travels possible in system,

where:

$$
I_{p}=\sum_{k=1}^{\text {nopf }} \sum_{J=1}^{\text {noptk }(k)}[n(J, K)-1]
$$

nopf - total number of part family or cell

nopfk $(k) \quad-$ total number of parts in $K^{\text {th }}$ cell

$J \quad-$ part number in a cell

$n(J, K) \quad-$ maximum number of operation required by $J^{\text {th }}$ part in $K^{\text {th }}$ cell

Number of intercell travels actually required by system,

$$
I_{r}=\sum_{J=1}^{p} \sum_{W(J)=1}^{(n(J)-1)} t_{n(J) W(J)}
$$


where:

$$
\begin{aligned}
& p \quad-\text { total number of parts in system (i.e. CF problem) } \\
& J \quad-J^{\text {th }} \text { part in system (i.e. CF problem) } \\
& n(Z) \quad-\text { maximum number of operation required for } J^{\text {th }} \text { part } \\
& t_{n(j) w(J)}=0 \text {, if operation } W(J) \& W(J)+1 \text { are performed in same cell. } \\
& =1 \text {, otherwise. }
\end{aligned}
$$

$$
G T E=\left(I_{p}-I_{r}\right) / I_{p}
$$

GTE does not involve ratio level data. Lokesh Kumar [17] proposed Ratio Grouping efficiency (RGE). It is defined as ratio of Machine utilization net gain (MUNG) to sum of machine utilization opportunity gain (MUOG), Intercell travel loss (ICTL) (i.e. value of exceptional elements) and void value (i.e. value of voids, $V V$ ).

Ratio grouping efficiency, $R G E=[M U N G /(M U O G+I C T L+V V)]$

$$
V V=\sum_{k=1}^{\text {nopf }} \sum_{I=1}^{\text {nomck }} \sum_{J=1}^{n+k f k(k)}\left[N_{v}(I, J, K) \cdot P L M(I, J, K) \cdot P V(I, J, K) / W_{p} f k(k)\right]
$$

where:

$\operatorname{nomck}(k)$ - number of machines in $K^{\text {th }}$ cell

$N_{v}(I, J, K)=0$, if $I^{\text {th }}$ machine, $J^{\text {th }}$ part in cell $K$ has occupied elements

$=1$, if $I^{\text {th }}$ machine, $J^{\text {th }}$ part in cell $K$ is a vacant element

$P L M(I, J, K)$ - operation time of $I^{\text {th }}$ machine for $J^{\text {th }}$ part in $K^{\text {th }}$ cell

$P V(I, J, K) \quad$ - production volume of $I^{\text {th }}$ part in $k^{\text {th }}$ cell

$$
I C T L=\sum_{I_{1}=1}^{n_{e}}\left[t_{h}\left(I_{1}, J_{e}\right) \cdot P V\left(1, J_{e}\right)+t_{c}\left(J_{e}\right)\right]
$$

$n_{e} \quad-$ number of exceptional elements

$P V(1, J) \quad$ - part production volume of $J_{e}^{\text {th }}$ exceptional part

$t_{h}\left(I_{1}, J\right) \quad$ - handling time for $J_{e}^{\text {th }}$ exceptional part

$t_{c}\left(J_{e}\right) \quad-$ transportation time for $J_{e}^{\text {th }}$ exceptional part

Setup time $(I, J, K)$ - setup time for $I^{\text {th }}$ machine, $J^{\text {th }}$ part in $K^{\text {th }}$ cell

(one can also take load/unload \& other idle times in account) [12].

Incorporating ordinal level and ratio level data, a general model of Performance measure is proposed [17] Weighted Sequence Ratio Efficiency (WSRE). It is represented by Eq. (14):

$$
W S R E=\alpha \cdot(R G E)+(1-\alpha) \cdot G T E
$$

where $\alpha$ is a constant ranging from zero to one [17].

Nair \& Narendran (1999) and also George et al. (2003) considered minimum within-cellload variation, minimum intercell travel volume \& combined objective function of these two conflicting objectives, with ordinal level data \& ratio level data. Due to page limit constraint, readers are advised to refer to work by these authors.

\section{APORVUIT ALGORITHM}

Step-by-step procedure for solution is as follows:

Step 1 - Data representation and input:

Form Machine Sequence Part Matrix (MSPM), Machine Part Operation Time Matrix (MPOTM), PV, Machine Capacity (MC), Setup time (Setime) matrix etc. 
Step 2 - Form Part Load Ratio Matrix (PLRM), Part Machine to Machine Sequence Matrix (PMMSM), \& Part Machine to Machine Sequence Time Volume/Capacity Matrix (PMMSTV/CM) i.e. Part Machine to Machine Sequence Load Ratio Matrix for each part.

Step 3 - Form Machine Sequence Part Load Ratio (MSPLRM) Matrix.

Step 4 - Form Standardized Machine Sequence Part Load Volume (SMSPLRM) matrix.

Step 5 - Form Part-Part Correlation Matrix (PPCM).

Step 6 - Find principle components (i.e. eigen vectors and eigen values).

Step 7 - Perform Orthographic View Part Grouping Analysis (OVPGA) to group parts.

Step 8 - Form Machine Group by Computing \& Allocating on basis of MUNG, MUOG, and ICTL for each machine for different part families using Eq. (4), (5), (6), (7).

Step 9 - Compute performance parameter i.e. grouping efficiency, GTE, RGE, WSRE with incell load variation \& combined objective function.

\section{RESULT \& DISCUSSION}

\subsection{Problem of size - 5 parts and 5 machines}

We consider a problem of 5 machines and 5 parts to illustrate the algorithm. Matrices MSPM, MPOTM (machine operation time matrix), PV, MC, and Setime \& PLRM are shown by Table I. From MPOTM, $P V$ and $M C$ matrix PLRM are formed. For each part, $P M M S M, P M M S T / C M$ $\& P M M S T V / C M$ matrices are formed form matrix MSPM, MPOTM, $P V \& M C$ matrices. Now, $M S P L R M$ matrix for all parts is formed from PMMSTV/CM matrices for parts. From here standardized matrix, SMSPLRM is formed. From SMSPLRM matrix, correlation matrix PPCM between parts is formed. Now principle components are found. First two principle components are plotted as shown in Fig. 1. We got two part families with parts p1 and p5 in family 1 and parts p2, p3 and p4 in family 2 .

Now, machines are allocated to part families. We consider 0.1 minutes for loading/unloading and transportation time for AGV's from one cell to another cell. For machine 1, MUNG for family 1 is zero and 220 minutes for family 2 . Machine $\mathrm{m}_{1}$ is allocated to family 2. For machine $\mathrm{m}_{2}, M U N G$ is 51 minutes and 168 minutes for part family 1 and 2, respectively; $\mathrm{m}_{2}$ is allocated to part family 2 . For machine $\mathrm{m}_{3}, M U N G$ is 24 minutes and 127 minutes for part family 1 and family 2, respectively; $\mathrm{m}_{3}$ is allocated to part family 2 . For machine $\mathrm{m}_{4}, M U N G$ is 176 minutes and 75 minutes, for family 1 and family 2, respectively; $\mathrm{m}_{4}$ is allocated to family 1 . For machine $\mathrm{m}_{5}, M U N G$ is 215 minutes and 95 minutes for part family 1 and family 2, respectively; $\mathrm{m}_{4}$ is allocated to family 1 . For machine $\mathrm{m}_{5}, M U N G$ is 215 minutes and 95 minutes for part family 1 and family 2 respectively; $\mathrm{m}_{5}$ is allocated to family 1.

Therefore, machines $\mathrm{m}_{4}$ and $\mathrm{m}_{5}$ are with part family 1 of $\mathrm{p} 1$ and $\mathrm{p} 5$ and machines $\mathrm{m}_{1}, \mathrm{~m}_{2}$ and $\mathrm{m}_{3}$ are with part family 2 of parts p2, p3, and p4. These are shown in Table I.

\subsection{Problem of size - 10 parts and 8 machines}

We consider a problem of 10 parts and 8 machines. It is considered by Nair \& Narendran, 1998 (Accord) with ordinal, ratio level data \& unity production volume of all parts. We consider this problem with production volume data shown in Table IV. For Table IV, part families are obtained by Fig. 2 and solution is shown by Table IV. Part family 1 (p1, p5, p7, p9) has machine group $1\left(\mathrm{~m}_{2}, \mathrm{~m}_{3}\right)$. Part family 2 (p2, p4, p6, p10) has machine group $2\left(\mathrm{~m}_{4}\right.$, $\left.\mathrm{m}_{5}, \mathrm{~m}_{6}, \mathrm{~m}_{7}\right)$. Part family $3(\mathrm{p} 3, \mathrm{p} 8)$ has machine group $3\left(\mathrm{~m}_{1}, \mathrm{~m}_{8}\right)$. It has group technology efficiency (GTE) 68.2 \%, same as by Nair \& Narendran (also for other results). Within-cell- 
load variation index is 0.758 . Combined objective function is 0.517 . Number of exceptional elements and intercell travels are 8 and 7, respectively, same as by Nair \& Narendran.

\subsection{Problem of size - 12 parts and 10 machines}

We consider a problem of 12 parts and 10 machines. The problem is considered by George et al. (2003). They considered production volume of all parts as unity. For this, we got solution shown by Table V. The configuration is the same as by George et al. (i.e. same part families and machine groups). Number of exceptional elements and number of intercell travel are 5 and 5, respectively, same as by George et al. GTE is $80 \%$, same as by George et al. Withincell-load variation index is 0.80125 and combined objective function is 0.641 , both the same as by George et al. RGE is $81.16 \%$. WSRE is $80.58 \%$.

1. Consideration of production volume mixes with ordinal and ratio level data We consider three variants of this problem with three production volume mixes shown in Table V, Table VI, and Table VII. Ordinal and ratio level data are same in all three variants as considered by George et al. (2003). The three corresponding configurations obtained, are shown by Table V, Table VI and Table VII, respectively. Part grouping is shown by Fig. 3, same for the three variants as in George et al.

For Table V, the number of exception elements is 5. GTE is $80 \%, R G E$ is $86.942 \%$. WSRE is $83.471 \%$. For Table VI, the number of exceptional elements is 5 . GTE is $80 \%$. RGE is $87.727 \%$. WSRE is $83.864 \%$. For Table VII, the number of exceptional elements is 4. GTE is $84.0 \%$. RGE is $89.48 \%$, WSRE is $86.74 \%$.

\section{Two way ANOVA for Validation}

In order to validate the proposition of section 4.3-1, analysis of variance has been employed. The ANOVA [21, 24] technique is important in the context of those situations where we want to compare more than two populations. The essence of ANOVA is that the total amount of variation in a set of data is broken down into two types, the amount which can be attributed to chance and that amount which can be attributed to specified causes. In general, through ANOVA technique, one can investigate any number of factors which are hypothesized or said to influence the dependent variable.

In case, we investigate two factors at the same time, then we use two-way ANOVA. In our case, we are concerned with influence of two factors, namely cell configuration and production volume mixes of parts on manufacturing system performance (i.e. Weighted Sequence Ratio Efficiency, WSRE).

Null hypothesis, $H_{0}$ : there is no significant influence of cell configurations and production volume mixes of parts on manufacturing system performance.

Alternate hypothesis, $H_{1}$ : (1) Do configurations influence system performance differently (i.e. column treatments)? (2) Do production volume mixes (i.e. row treatments) influence system performance differently (i.e. row treatments)?

On simulated example, $F$ ratio is enumerated and given in Table VIII. Sum of squares of deviations for total variance or total SS is 65.94. Sum of squares of deviations for variance between columns or SS between column treatments (i.e between configurations) is 25.20. Sum of squares of deviations for variance between rows or SS between rows treatments (i.e. between production volume mixes) is 39.6. Sum of squares of deviations for residual or error variance is 1.1394 . Similarly degree of freedom $(d f)$, mean square i.e. estimation of variance (MS), calculated F-ratio and tabular F-limit are given in Table VIII.

Calculated $F$-ratio is 44.243 between configurations is greater than tabular $F(2,4)=18$ for 0.01 level of significance. Also, calculated $F$-ratio 69.530 between production volume 
mixes is greater than $F(2,4)=18$ for 0.01 level of significance. So hypothesis $H_{1}$ is correct. Therefore, configuration and production volume mixes of parts has significant influence on manufacturing system performance.

Now, it is clear that production volume is an important factor for cell configuration while considering ratio level and ordinal level data. For product volume mixes given in Table V, VI and VII corresponding cell configurations given in Table V, VI, and VII should be used. Therefore, with change in production volume mixes, new cell configuration should be determined by using APORVUIT algorithm. ANOVA analysis should be performed to determine whether there is significant performance difference among old and new proposed configuration required by production mixed change or not. If there is significant performance difference, and management also desires, cell configuration may be changed. Also corresponding capacity may be scaled up/down.

Due to length of paper constraint, other size problem on test data set can not be included in the paper. It is observed that APORVUIT gives satisfactory results which are of good quality or same as in existing literature $[14,16]$ in its class. Research papers $[15,16]$ are important benchmark papers in the field of CMS design. These are referred by many researchers. For instance, Seifoddini referred it in 2007 [25]. Seifoddini has taken ordinal level data that is machine sequence and ratio level data as production volume in his SCM model. However, he did not consider other important shop floor realities that are operation time and machine capacity in his SCM model. Seifoddini, a renowned researcher, published several papers on cellular manufacturing system design as early as 1986 [26].

Table I: Input and Output $M S P M$, MPOTM, PV, MC \& Setime matrix of size $5 \times 5$.

\begin{tabular}{|c|c|c|c|c|c|c|c|}
\hline \multicolumn{2}{|c|}{ Parts $\rightarrow$} & \multirow[b]{2}{*}{ p1 } & \multirow[b]{2}{*}{ p5 } & \multirow[b]{2}{*}{ p2 } & \multirow[b]{2}{*}{ p3 } & \multirow[b]{2}{*}{ p4 } & \multirow[b]{2}{*}{ MC } \\
\hline $\mathbf{M c} \downarrow$ & $\begin{array}{l}\text { OS/ } \\
\text { OT }\end{array}$ & & & & & & \\
\hline \multirow[b]{2}{*}{$\mathbf{m}_{4}$} & OS & 2 & 1 & 0 & 0 & 1 & \multirow[t]{2}{*}{200} \\
\hline & OT & 6 & 2 & 0 & 0 & 2 & \\
\hline \multirow{2}{*}{$\mathbf{m}_{5}$} & OS & 3 & 3 & 0 & 4 & 0 & \multirow[t]{2}{*}{120} \\
\hline & OT & 5 & 4 & 0 & 2 & 0 & \\
\hline \multirow{2}{*}{$\mathbf{m}_{1}$} & OS & 0 & 0 & 1 & 3 & 3 & \multirow[t]{2}{*}{130} \\
\hline & OT & 0 & 0 & 4 & 2 & 2 & \\
\hline \multirow[b]{2}{*}{$\mathbf{m}_{2}$} & OS & 1 & 0 & 0 & 1 & 2 & \multirow[t]{2}{*}{150} \\
\hline & OT & 3 & 0 & 0 & 2 & 1 & \\
\hline \multirow[b]{2}{*}{$\mathbf{m}_{3}$} & OS & 0 & 2 & 2 & 2 & 0 & \multirow[t]{2}{*}{120} \\
\hline & OT & 0 & 1 & 3 & 2 & 0 & \\
\hline \multicolumn{2}{|l|}{$P V$} & 20 & 30 & 10 & 50 & 40 & \\
\hline \multicolumn{2}{|c|}{ Setime } & 0.5 & 0.75 & 1.25 & 0.92 & 1.0 & \\
\hline
\end{tabular}

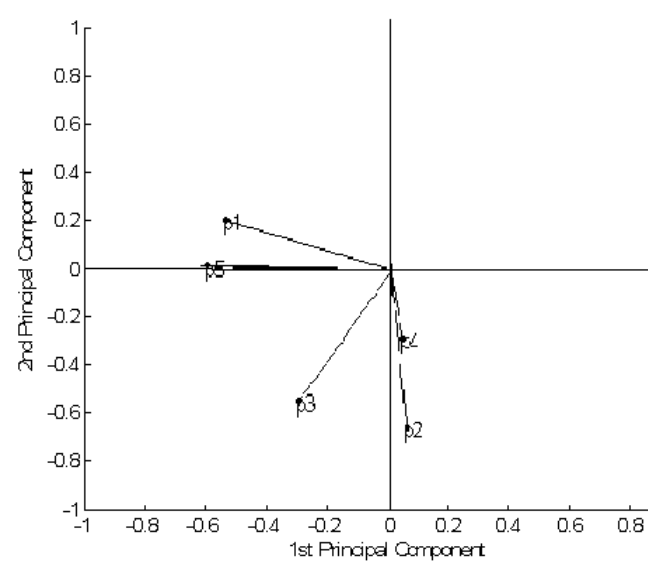

Figure 1: Orthographic View Part Grouping; problem 1: part machine $\left(\mathrm{p} 1 \times \mathrm{m}_{1}\right)$ size $5 \times 5$.
Table II: PMMSM, PMMSTV/CM of size $5 \times 5$ for part $\mathrm{p} 1$.

\begin{tabular}{|c|c|c|c|c|c|c|}
\hline \multicolumn{2}{|c|}{ Machine } & \multirow[b]{2}{*}{$\mathbf{m}_{1}$} & \multirow[b]{2}{*}{$\mathbf{m}_{2}$} & \multirow[b]{2}{*}{$\mathbf{m}_{3}$} & \multirow[b]{2}{*}{$\mathbf{m}_{4}$} & \multirow[b]{2}{*}{$\mathbf{m}_{5}$} \\
\hline $\begin{array}{r}\text { Mc } \\
\downarrow\end{array}$ & $\begin{array}{c}\overrightarrow{\mathrm{OS}} \\
/ \mathrm{OT} \\
/ \mathbf{P V}\end{array}$ & & & & & \\
\hline \multirow[b]{2}{*}{$\mathbf{m}_{1}$} & OS & 0 & 0 & 0 & 0 & 0 \\
\hline & RT & 0 & 0 & 0 & 0 & 0 \\
\hline \multirow[b]{2}{*}{$\mathbf{m}_{2}$} & OS & 0 & 1 & 0 & 1 & 1 \\
\hline & RT & 0 & 0.4 & 0 & 0.4 & 0.4 \\
\hline \multirow[b]{2}{*}{$\mathbf{m}_{3}$} & OS & 0 & 0 & 0 & 0 & 0 \\
\hline & RT & 0 & 0 & 0 & 0 & 0 \\
\hline \multirow[b]{2}{*}{$\mathbf{m}_{4}$} & OS & 0 & 0 & 0 & 1 & 1 \\
\hline & RT & 0 & 0 & 0 & 0.6 & 0.6 \\
\hline \multirow[b]{2}{*}{$\mathbf{m}_{5}$} & os & 0 & 0 & 0 & 0 & 1 \\
\hline & RT & 0 & 0 & 0 & 0 & 0.83 \\
\hline
\end{tabular}

Remark:

OS - Operation Sequence,

OT - Operation Time,

$P V$ - Production Volume,

Setime - Setup time,

$M C$ - Machine (m),

A.I.A.C.- An Analytical Iterative Cluster

$O T$ - operation time minutes ,

$R T=O T \times P V / M C$

$M C$ - Machine capacity in

minutes
Table III: Machine

Sequence Part

Load Ratio

Matrix

(MSPLRM).

\begin{tabular}{|l|l|l|l|l|}
\hline $\mathbf{p 1}$ & $\mathbf{p 2}$ & $\mathbf{p 3}$ & $\mathbf{p 4}$ & $\mathbf{p 5}$ \\
\hline 0 & .301 & .77 & .61 & 0 \\
\hline 0 & 0 & 0 & 0 & 0 \\
\hline 0 & .301 & 0 & 0 & 0 \\
\hline 0 & 0 & 0 & 0 & 0 \\
\hline 0 & 0 & .77 & 0 & 0 \\
\hline 0 & 0 & .33 & .8 & 0 \\
\hline 0.4 & 0 & .33 & .8 & 0 \\
\hline 0 & 0 & .33 & 0 & 0 \\
\hline 0.4 & 0 & 0 & 0 & 0 \\
\hline 0.4 & 0 & .33 & 0 & 0 \\
\hline 0 & 0 & .83 & 0 & 0 \\
\hline 0 & 0 & 0 & 0 & 0 \\
\hline 0 & 0.25 & .83 & 0 & 0.25 \\
\hline 0 & 0 & 0 & 0 & 0 \\
\hline 0 & 0 & .83 & 0 & 0.25 \\
\hline 0 & 0 & 0 & .4 & 0 \\
\hline 0 & 0 & 0 & .4 & 0 \\
\hline 0 & 0 & 0 & 0 & .3 \\
\hline 0.6 & 0 & 0 & .4 & .3 \\
\hline 0.6 & 0 & 0 & 0 & 0.3 \\
\hline 0 & 0 & 0 & 0 & 0 \\
\hline 0 & 0 & 0 & 0 & 0 \\
\hline 0 & 0 & 0 & 0 & 0 \\
\hline 0 & 0 & 0 & 0 & 0 \\
\hline 0.83 & 0 & .83 & 0 & 1.0 \\
\hline & & & &
\end{tabular}


Kumar, Jain: Part-Machine Group Formation with Ordinal-Ratio Level Data \& Production ...

Table IV: Output Machine Sequence Part Matrix, MSPM (8x10).

\begin{tabular}{|c|c|c|c|c|c|c|c|c|c|c|c|}
\hline \multicolumn{2}{|r|}{ Parts $\rightarrow$} & \multirow{2}{*}{ p1 } & \multirow{2}{*}{ p5 } & \multirow{2}{*}{ p7 } & \multirow{2}{*}{ p9 } & \multirow{2}{*}{ p2 } & \multirow{2}{*}{ p4 } & \multirow{2}{*}{ p6 } & \multirow{2}{*}{ p10 } & \multirow{2}{*}{ p3 } & \multirow{2}{*}{ p8 } \\
\hline Mc $\downarrow$ & Sequence/ratio & & & & & & & & & & \\
\hline \multirow{2}{*}{$\mathbf{m}_{2}$} & Sequence & 3 & 3 & 2 & 1 & 0 & 0 & 0 & 5 & 0 & 0 \\
\hline & Ratio & 0.9 & 0.9 & 0.5 & 0.3 & 0 & 0 & 0 & 0.6 & 0 & 0 \\
\hline \multirow[b]{2}{*}{$\mathbf{m}_{3}$} & Sequence & 1 & 1 & 1 & 2 & 0 & 0 & 0 & 0 & 0 & 0 \\
\hline & Ratio & 0.9 & 0.9 & 0.5 & 0.3 & 0 & 0 & 0 & 0 & 0 & 0 \\
\hline \multirow{2}{*}{$\mathbf{m}_{4}$} & Sequence & 0 & 0 & 0 & 0 & 2 & 2 & 3 & 1 & 0 & 0 \\
\hline & Ratio & 0 & 0 & 0 & 0 & 0.8 & 0.8 & 0.8 & 0.6 & 0 & 0 \\
\hline \multirow{2}{*}{$\mathbf{m}_{5}$} & Sequence & 0 & 0 & 0 & 0 & 3 & 3 & 2 & 0 & 0 & 0 \\
\hline & Ratio & 0 & 0 & 0 & 0 & 0.8 & 0.8 & 0.8 & 0 & 0 & 0 \\
\hline \multirow[b]{2}{*}{$\mathbf{m}_{6}$} & Sequence & 2 & 2 & 0 & 0 & 0 & 1 & 1 & 0 & 0 & 0 \\
\hline & Ratio & 0.6 & 0.3 & 0 & 0 & 0 & 0.4 & 0.4 & 0 & 0 & 0 \\
\hline \multirow[b]{2}{*}{$\mathbf{m}_{7}$} & Sequence & 0 & 0 & 0 & 0 & 4 & 0 & 4 & 2 & 3 & 3 \\
\hline & Ratio & 0 & 0 & 0 & 0 & 0.8 & 0 & \begin{tabular}{|l|}
0.8 \\
\end{tabular} & 0.15 & 0.15 & 0.15 \\
\hline \multirow{2}{*}{$\mathbf{m}_{1}$} & Sequence & 0 & 0 & 0 & 0 & 1 & 0 & 0 & 3 & 1 & 2 \\
\hline & Ratio & 0 & 0 & 0 & 0 & 0.4 & 0 & 0 & 0.6 & 0.6 & 0.6 \\
\hline \multirow{2}{*}{$\mathbf{m}_{8}$} & Sequence & 0 & 0 & 0 & 0 & 0 & 0 & 0 & 4 & 2 & 1 \\
\hline & Ratio & 0 & 0 & 0 & 0 & 0 & 0 & 0 & 0.6 & 0.6 & 0.6 \\
\hline \multicolumn{2}{|l|}{$P V$} & 12 & 40 & 75 & 45 & 75 & 60 & 90 & 80 & 120 & 110 \\
\hline \multicolumn{2}{|c|}{ Setime } & 0.5 & 1.0 & 1.5 & 1.4 & 0.75 & 0.92 & 0.33 & 0.8 & 1.25 & 1.75 \\
\hline
\end{tabular}

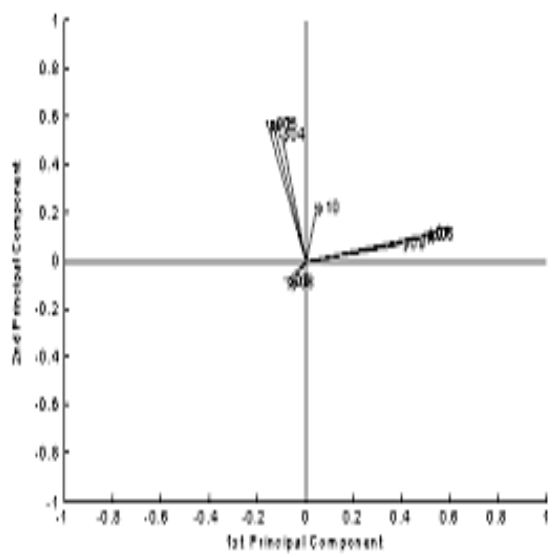

Figure 2: Orthographic View Part Grouping; problem 2: part machine $\left(\mathrm{p} 1 \times \mathrm{m}_{1}\right)$ size $8 \times 10$.

Table V: Output Machine Sequence Part Matrix, MSPM.

\begin{tabular}{|c|c|c|c|c|c|c|c|c|c|c|c|c|c|}
\hline \multicolumn{2}{|c|}{ Parts $\rightarrow$} & \multirow[b]{2}{*}{ p1 } & \multirow[b]{2}{*}{ p5 } & \multirow[b]{2}{*}{ p9 } & \multirow[b]{2}{*}{ p10 } & \multirow[b]{2}{*}{ p2 } & \multirow[b]{2}{*}{ p3 } & \multirow[b]{2}{*}{ p7 } & \multirow[b]{2}{*}{ p8 } & \multirow[b]{2}{*}{ p12 } & \multirow[b]{2}{*}{ P4 } & \multirow[b]{2}{*}{ p6 } & \multirow[b]{2}{*}{ p11 } \\
\hline $\begin{array}{c}\text { Mc } \\
\downarrow\end{array}$ & $\begin{array}{l}\text { Sequence/ } \\
\text { ratio }\end{array}$ & & & & & & & & & & & & \\
\hline \multirow{2}{*}{$\mathbf{m}_{1}$} & Sequence & 0 & 3 & 2 & 3 & 0 & 0 & 0 & 0 & 0 & 0 & 0 & 0 \\
\hline & Ratio & 0 & 0.63 & 0.54 & 0.39 & 0 & 0 & 0 & 0 & 0 & 0 & 0 & 0 \\
\hline \multirow[b]{2}{*}{$\mathbf{m}_{3}$} & Sequence & 1 & 5 & 1 & 1 & 0 & 0 & 0 & 0 & 0 & 0 & 0 & 0 \\
\hline & Ratio & 0.96 & \begin{tabular}{l|}
0.97 \\
\end{tabular} & $\begin{array}{ll}0.92 \\
\end{array}$ & 0.61 & 0 & 0 & 0 & 0 & 0 & 0 & 0 & 0 \\
\hline \multirow{2}{*}{$\mathbf{m}_{4}$} & Sequence & 2 & 4 & 0 & 0 & 0 & 0 & 0 & 0 & 0 & 1 & 1 & 0 \\
\hline & Ratio & 0.95 & 0.89 & 0 & 0 & 0 & 0 & 0 & 0 & 0 & 0.07 & 0.11 & 0 \\
\hline \multirow{2}{*}{$\mathbf{m}_{6}$} & Sequence & 3 & 1 & 2 & 2 & 0 & 0 & 0 & 0 & 0 & 0 & 0 & 0 \\
\hline & Ratio & 0.63 & 0.61 & 0.72 & 0.72 & 0 & 0 & 0 & 0 & 0 & 0 & 0 & 0 \\
\hline \multirow[b]{2}{*}{$\mathbf{m}_{8}$} & Sequence & 0 & 2 & 3 & 0 & 4 & 1 & 0 & 0 & 1 & 0 & 0 & 0 \\
\hline & Ratio & 0 & 0.94 & 0.92 & 0 & 0.04 & 0.08 & 0 & 0 & 0.02 & 0 & 0 & 0 \\
\hline \multirow{2}{*}{$\mathbf{m}_{2}$} & Sequence & 0 & 0 & 0 & 0 & 1 & 2 & 1 & 1 & 3 & 0 & 0 & 0 \\
\hline & Ratio & 0 & 0 & 0 & 0 & 0.86 & 0.88 & 1.2 & 1.0 & 0.7 & 0 & 0 & 0 \\
\hline \multirow[b]{2}{*}{$\mathbf{m}_{5}$} & Sequence & 0 & 0 & 0 & 0 & 3 & 4 & 3 & 0 & 2 & 0 & 0 & 0 \\
\hline & Ratio & 0 & 0 & 0 & 0 & 0.54 & 0.49 & 0.81 & 0 & 0.72 & 0 & 0 & 0 \\
\hline \multirow[b]{2}{*}{$\mathbf{m}_{10}$} & Sequence & 0 & 0 & 0 & 0 & 2 & 3 & 2 & 2 & 0 & 0 & 0 & 0 \\
\hline & Ratio & 0 & 0 & 0 & 0 & 0.67 & 0.73 & 0.83 & 0.62 & 0 & 0 & 0 & 0 \\
\hline \multirow{2}{*}{$\mathbf{m}_{7}$} & Sequence & 0 & 0 & 0 & 0 & 0 & 0 & 0 & 0 & 0 & 3 & 3 & 1 \\
\hline & Ratio & 0 & 0 & 0 & 0 & 0 & 0 & 0 & 0 & 0 & 0.83 & 0.99 & 0.77 \\
\hline \multirow{2}{*}{$\mathbf{m}_{9}$} & Sequence & 0 & 0 & 0 & 0 & 0 & 0 & 0 & 0 & 0 & 2 & 2 & 0 \\
\hline & Ratio & 0 & 0 & 0 & 0 & 0 & 0 & 0 & 0 & 0 & 0.72 & 0.76 & 0 \\
\hline \multicolumn{2}{|l|}{$P V$} & 12 & 40 & 45 & 80 & 75 & 120 & 150 & 75 & 110 & 60 & 90 & 25 \\
\hline \multicolumn{2}{|c|}{ Setime } & 0.5 & 1.0 & 1.4 & 0.8 & 0.75 & 1.25 & 0.66 & 1.5 & 1.75 & \begin{tabular}{l|l}
0.92 \\
\end{tabular} & 0.33 & 0.6 \\
\hline
\end{tabular}

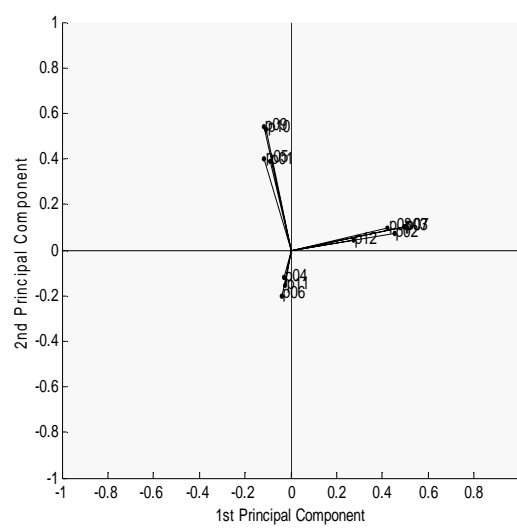

Figure 3: Orthographic View Part Grouping; problem 3: part machine $\left(\mathrm{p} 1 \times \mathrm{m}_{1}\right)$ size $10 \times 12$.

Table VI: Output Machine Sequence Part Matrix, MSPM.

\begin{tabular}{|c|c|c|c|c|c|c|c|c|c|c|c|c|c|}
\hline \multicolumn{2}{|c|}{ Parts $\rightarrow$} & \multirow[b]{2}{*}{ p1 } & \multirow[b]{2}{*}{ p5 } & \multirow[b]{2}{*}{ p9 } & \multirow[b]{2}{*}{ p10 } & \multirow[b]{2}{*}{ p2 } & \multirow[b]{2}{*}{ p3 } & \multirow[b]{2}{*}{ p7 } & \multirow[b]{2}{*}{ p8 } & \multirow[b]{2}{*}{ p12 } & \multirow[b]{2}{*}{ p4 } & \multirow[b]{2}{*}{ p6 } & \multirow[b]{2}{*}{ p11 } \\
\hline $\mathbf{M c} \downarrow$ & $\begin{array}{l}\text { Sequence } \\
\text { /ratio }\end{array}$ & & & & & & & & & & & & \\
\hline $\mathrm{m}_{1}$ & Sequence & 0 & 3 & 4 & 3 & 0 & 0 & 0 & 0 & 0 & 0 & 0 & 0 \\
\hline $\mathbf{m}_{3}$ & Sequence & 1 & 5 & 1 & 1 & 0 & 0 & 0 & 0 & 0 & 0 & 0 & 0 \\
\hline $\mathbf{m}_{6}$ & Sequence & 3 & 1 & 2 & 2 & 0 & 0 & 0 & 0 & 0 & 0 & 0 & 0 \\
\hline m8 & Sequence & 0 & 2 & 3 & 0 & 4 & 1 & 0 & 0 & 1 & 0 & 0 & 0 \\
\hline $\mathbf{m}_{2}$ & Sequence & 0 & 0 & 0 & 0 & 1 & 2 & 1 & 1 & 3 & 0 & 0 & 0 \\
\hline $\mathbf{m}_{5}$ & Sequence & 0 & 0 & 0 & 0 & 3 & 4 & 3 & 0 & 2 & 0 & 0 & 0 \\
\hline $\mathbf{m}_{10}$ & Sequence & 0 & 0 & 0 & 0 & 2 & 3 & 2 & 2 & 0 & 0 & 0 & 0 \\
\hline $\mathbf{m}_{4}$ & Sequence & 2 & 4 & 0 & 0 & 0 & 0 & 0 & 0 & 0 & 1 & 1 & 0 \\
\hline $\mathbf{m}_{7}$ & Sequence & 0 & 0 & 0 & 0 & 0 & 0 & 0 & 0 & 0 & 3 & 3 & 1 \\
\hline $\mathbf{m}_{9}$ & Sequence & 0 & 0 & 0 & 0 & 0 & 0 & 0 & 0 & 0 & 2 & 2 & 0 \\
\hline \multicolumn{2}{|l|}{$P V$} & 12 & 20 & 45 & 80 & 75 & 120 & 150 & 75 & 110 & 120 & 150 & 25 \\
\hline \multicolumn{2}{|c|}{ Setime } & 0.5 & 1.0 & 1.4 & 0.8 & 0.75 & 1.25 & 0.66 & 1.5 & 1.75 & 0.92 & 0.33 & 0.6 \\
\hline
\end{tabular}


Table VII: Output Machine Sequence Part Matrix, MSPM.

\begin{tabular}{|c|c|c|c|c|c|c|c|c|c|c|c|c|c|}
\hline \multicolumn{2}{|r|}{ Parts $\rightarrow$} & \multirow[b]{2}{*}{ p1 } & \multirow[b]{2}{*}{ p5 } & \multirow[b]{2}{*}{ p9 } & \multirow[b]{2}{*}{ p10 } & \multirow[b]{2}{*}{ p2 } & \multirow[b]{2}{*}{ p3 } & \multirow[b]{2}{*}{ p7 } & \multirow[b]{2}{*}{ p8 } & \multirow[b]{2}{*}{ p12 } & \multirow[b]{2}{*}{ p4 } & \multirow[b]{2}{*}{ p6 } & \multirow[b]{2}{*}{ p1 } \\
\hline $\mathbf{M c} \downarrow$ & $\begin{array}{l}\text { Sequence/ } \\
\text { ratio }\end{array}$ & & & & & & & & & & & & \\
\hline $\mathbf{m}_{1}$ & Sequence & 0 & 3 & 4 & 3 & 0 & 0 & 0 & 0 & 0 & 0 & 0 & 0 \\
\hline $\mathbf{m}_{3}$ & Sequence & 1 & 5 & 1 & 1 & 0 & 0 & 0 & 0 & 0 & 0 & 0 & 0 \\
\hline $\mathbf{m}_{6}$ & Sequence & 3 & 1 & 2 & 2 & 0 & 0 & 0 & 0 & 0 & 0 & 0 & 0 \\
\hline $\mathbf{m}_{2}$ & Sequence & 0 & 0 & 0 & 0 & 1 & 2 & 1 & 1 & 3 & 0 & 0 & 0 \\
\hline $\mathrm{m}_{5}$ & Sequence & 0 & 0 & 0 & 0 & 3 & 4 & 3 & 0 & 2 & 0 & 0 & 0 \\
\hline $\mathbf{m}_{8}$ & Sequence & 0 & 2 & 3 & 0 & 4 & 1 & 0 & 0 & 1 & 0 & 0 & 0 \\
\hline $\mathbf{m}_{10}$ & Sequence & 0 & 0 & 0 & 0 & 2 & 3 & 2 & 2 & 0 & 0 & 0 & 0 \\
\hline $\mathbf{m}_{4}$ & Sequence & 2 & 4 & 0 & 0 & 0 & 0 & 0 & 0 & 0 & 1 & 1 & 0 \\
\hline $\mathbf{m}_{7}$ & Sequence & 0 & 0 & 0 & 0 & 0 & 0 & 0 & 0 & 0 & 3 & 3 & 1 \\
\hline $\mathbf{m}_{9}$ & Sequence & 0 & 0 & 0 & 0 & 0 & 0 & 0 & 0 & 0 & 2 & 2 & 0 \\
\hline \multicolumn{2}{|l|}{$P V$} & 12 & 20 & 22 & 80 & 75 & 120 & 150 & 75 & 110 & 120 & 150 & 25 \\
\hline \multicolumn{2}{|c|}{ Setime } & 0.5 & 1.0 & 1.4 & 0.8 & 0.75 & 1.25 & 0.66 & 1.5 & 1.75 & 0.92 & 0.33 & 0.6 \\
\hline
\end{tabular}

Table VIII: Two way ANOVA analysis.

\begin{tabular}{|l|l|l|l|l|l|l|}
\hline Source of variance & $\boldsymbol{S S}$ & $\boldsymbol{d} \boldsymbol{f}$ & $\boldsymbol{M S}$ & F-ratio & F-limit (from table value) & comment \\
\hline $\begin{array}{l}\text { Treatment between columns (ie between } \\
\text { configurations) }\end{array}$ & 25.201 & 2 & 12.601 & 44.243 & $\begin{array}{l}\mathrm{F}(2,4)=6.94 \text { for 5 \% level =18 } \\
\text { for 1 \% level }\end{array}$ & significant \\
\hline $\begin{array}{l}\text { Between row treatments (ie between } \\
\text { production volume mixes ) }\end{array}$ & 39.0 & 2 & 19.8 & 69.530 & $\begin{array}{l}\mathrm{F}(2,4)=6.94 \text { for 5 \% level =18 } \\
\text { for 1\% level }\end{array}$ & significant \\
\hline Residual error & 1.1397 & 4 & 0.2848 & & & \\
\hline Total & 65.94 & 8 & & & & \\
\hline
\end{tabular}

\section{CONCLUSION}

In this work, a new algorithm, APORVUIT is proposed for formation of part families and machine groups with ordinal level data (i.e. operation sequence), ratio level data (i.e. operation time, production volume, machine capacity, setup time etc.), machine utilization \& intercell travel loss. Part families and machine groups evolve naturally and allow flexibility to designers to either identify the required number of cell in advance, or consider it as dependent variables. It is observed that production volume should be taken with ordinal and ratio level data based models, since it has significant influence on cell configuration and cell performance. To validate the propositions that production volume mixes and cell configuration have significant influence on cell performance, two way ANOVA [21, 24] techniques is used, and on simulated example the F-ratio is enumerated. It is concluded that the change in production volume mixes may need capacity scaling \& reconfiguration according to recommendations of algorithm, ANOVA analysis and management desire.

The performance of proposed algorithm, APORVUIT is comparable \& of good quality in its class $[14,16]$ in existing literature. APORVUIT is simple, easy to understand and implement, and supported by software. There is no need of complex optimization techniques and programming skills. For industrial application, Proposed Algorithm can be implemented by the use of free available software, Scilab - platform, as well as expensive commercial software such as SPSS, SAS, STAD, XLSTATS etc. One can develop one's programme easily in this easy and very user friendly software Scilab [27].

\section{REFERENCES}

[1] Adenso-Diaz, B.; Lozano, S.; Eguira, I. (2005). Part-machine grouping using weighted similarity coefficients, Computers \& Industrial Engineering, Vol. 48, 553-570

[2] Albadawi, Z.; Bashir, H. A.; Chen, M. (2005). A mathematical approach for the formation of Manufacturing cell, Computers \& Industrial Engineering, Vol. 48, 3-21 
[3] Arvindh, B.; Irani, S. A. (1991). Principal components analysis for evaluating the feasibility of cellular manufacturing without initial-part matrix clustering, International Journal of Production Research, Vol. 32, 1909-1938

[4] Cheng, C. H.; Goh, C. H.; Lee, A. (2001). Designing group technology manufacturing systems using heuristic branching rules, Computers \& Industrial engineering, Vol. 40, 117-131

[5] Genwook, J.; Leep, H. R.; Parsaaei, H. R. (1998). A cellular manufacturing system based on new similarity coefficient which considers alternative routes during machine failure, Computers \& Industrial Engineering, Vol. 34, 21-36

[6] Harhalakis, G.; Nagi, R.; Proth, J. M. (1990). An efficient heuristic in manufacturing cell formation for group technology applications, International Journal of Production Research, Vol. 28, No. 1, 185-198

[7] King, J. R.; Nakornchai, V. (1982). Machine-component group formation in group technology: review and extension, International Journal of Production Research, Vol. 20, 117-133

[8] Kitaoka, M.; Nakamura, R.; Seriza, S.; Usuki, J. (1999). Multivariate analysis model for machine-part cell formation problem in group technology, International Journal Production Economics, Vol. 60-61, 433-438

[9] Srinivasan, G.; Narendran, T. T. (1991). GRAFICS: a nonhierarchical clustering algorithm for group technology, International Journal of Production Research, Vol. 29, 463-478

[10] Stawowy, A. (2006). Evolutionary strategy for manufacturing cell design, The international Journal of Management Science: Omega, Vol. 34, 1-18

[11] Wang, J. (2003). Formation of machine cells and part families in cellular manufacturing systems using a linear assignment algorithm, Automatica, Vol. 39, 1607-1615

[12] Yasuda, K.; Yin, Y. (2001). A dissimilarity measure for solving the cell formation problem in cellular manufacturing, Computers \& Industrial Engineering, Vol. 39, 1-17

[13] Yin, Y.; Kazuhiko, K. (2006). Similarity coefficient methods applied to the cell formation problem: A taxonomy and review, International Journal of Production Economics, Vol. 101, 329-352

[14] George, A. P.; Rajendran, C.; Ghosh, S. (2003). An analytical-iterative clustering algorithm for cell formation in cellular manufacturing systems with ordinal-level and ratio-level data. International Journal of Advanced Manufacturing Technology, Vol. 22, 125-133

[15] Nair, J. G.; Narendran, T. T. (1998). CASE: A clustering algorithm for cell formation with sequence data, International Journal on Production Research, Vol. 36, No. 1, 157-179

[16] Nair, J. G.; Narendran, T. T. (1999). ACCORD: A bicriterion algorithm for cell formation using ordinal and ratio-level data, International Journal of Production Research, Vol. 37, 539-556

[17] Kumar, L.; Jain, P. K. (2008). Part-Machine Group Formation with Operation Sequence, Time and Production Volume, International Journal of Simulation Modelling, Vol. 7, No. 4, 198-209

[18] Selim, H. M.; Askin, R. G.; Vakharia, A. J. (1998). Cell formation in-group technology: review, evaluation and direction for future research, Computers and Industrial Engineering, Vol. 34, No. 1, 3-20

[19] Kusiak, A.; Wang, J. (1993). Efficient organizing of design activities, International Journal of Production Research, Vol. 31, No. 4, 753-769

[20] Gonzalez, R. C.; Wintz, P. (1987). Digital Image Processing, Addison-Wesley Publishing Company, New York

[21] Panneerselvam, R. (2004). Research Methodology, Prentice Hall of India, New Delhi

[22] Gnanadesikan, R. (1997). Methods for Statistical Data Analysis of Multivariate observations, Wiley, New York, 7-15

[23] Rummel, R. J. (1988). Applied factor analysis, Northwestern University Press, Evanston

[24] Kothari, C. R. (2004). Research Methodology, New Age Publisher, New Delhi

[25] Alhourani, F.; Seifoddini, H. (2007). Machine cell formation for production management in cellular manufacturing systems, International Journal of Production research, Vol. 45 No. 4, 913-934

[26] Seifoddini, H.; Wolfe, P. M. (1986). Application of similarity coefficient method in GT, IIE Transactions, Vol. 21, 382-388

[27] Scilab: Platform - Scilab.org/ Platform 